\title{
OPTIMAL TIMING FOR POST EMERGENCE APPLICATIONS OF NICOSULFURON FOR WEED CONTROL IN MAIZE
}

\author{
T.K. JAMES ${ }^{1}$, A. RAHMAN and M. TROLOVE \\ AgResearch, Ruakura Research Centre, Private Bag 3123, Hamilton, \\ New Zealand
}

Corresponding author: trevor.james@agresearch.co.nz

\begin{abstract}
Field trials were conducted over three growing seasons to ascertain optimal timing for post emergence application of nicosulfuron in maize when no pre-emergence herbicides were used. Nicosulfuron $(60 \mathrm{~g} / \mathrm{ha})$ was applied at 1 to 7 weeks after maize emergence. Dry matter and leaf area of maize plants, grass and broadleaf weeds were determined at the time of treatment. Maize grain yields were used as the major determinant to assess the impact of different timings of post-emergence weed control. The early season (weeks 1-3) weed control achieved with nicosulfuron was excellent, but subsequent germination of weeds occurred. In weeks 4-7 the larger weeds took longer to brown off and die back. Results showed that both the biomass and ground cover of weeds were important in determining the duration of the optimal application window. When weeds remained uncontrolled and achieved $100 \%$ ground cover, grain yields were significantly reduced. This occurred at weeks 3, 5 and 6 after emergence in the three trials.
\end{abstract}

Keywords: nicosulfuron, weed control, post-emergence, maize, weed competition.

\section{INTRODUCTION}

The sulfonylurea herbicide nicosulfuron has been demonstrated to give post-emergence control of several difficult to control grass weeds in maize (Zea mays) and soya bean (Glycine max) crops (Kimura et al. 1989; Mekki \& Leroux 1994). It can be used postemergence to either supplement or replace certain pre-emergence treatments in maize or as an alternative to high application rates of pre-emergence herbicides on high organic matter soils. Of the main annual grass weeds present in New Zealand maize crops (Rahman et al. 2003), nicosulfuron provided good control of smooth witchgrass (Panicum dichotomiflorum) and barnyard grass (Echinochloa crus-galli) and suppression of most other annual and perennial grasses as well as many broadleaf weeds (Rahman \& James 1993; Kapusta et al. 1994). Further field trials showed that addition of an adjuvant helped considerably improve the effectiveness of nicosulfuron on these weeds (James \& Rahman 1993, 1997).

The success of post-emergence weed management often depends upon application timing and weed seedling size. If the application is too early in the season, the short residual life means that it fails to control subsequent weed germination. Conversely, late applications suffer reduced efficacy as the weeds exceed the $200 \mathrm{~mm}$ tall recommended size (Carey \& Kells 1995; Williams \& Harvey 2000).

Control of grass weeds, particularly the perennial species like couch (Elytrigia repens) and Mercer grass (Paspalum distichum), with post-emergence herbicides is often difficult because their leaves usually emerge slowly, well after the maize crop has been planted, and by the time they have sufficient leaf material for adequate herbicide efficacy, the crop is well advanced. However, the tolerance of maize, particularly the sweet corn cultivars, 
has been shown to be less and the level of injury increased when nicosulfuron was applied late, i.e. at the 7-8 leaf stage of the crop (Robinson et al. 1993). Also, maize growers are sometimes not able to apply the post-emergence treatment at the optimum stage.

The field trials reported here were therefore conducted to investigate the efficacy and crop tolerance of nicosulfuron at different application times from one week after crop emergence until full canopy cover of the crop. A specific insight sought was to determine the effect of the weeds present up to the time of spraying on growth and yield of the maize crop.

\section{MATERIALS AND METHODS}

Three trials were carried out in consecutive years from 1998 to 2000. Trial 1 was on a Bruntwood silt loam (58\% sand, $15 \%$ clay, $6.2 \%$ organic carbon and $\mathrm{pH} 5.8$ ) while Trials 2 and 3 were on a Horotiu silt loam (19\% sand, 23\% clay, 5.5\% organic carbon and $\mathrm{pH}$ 5.9). Key information on the trials is presented in Table 1. In Trials 1 and 2, individual plots were $3 \times 10 \mathrm{~m}$ containing four planted rows and were laid out in a complete randomised block design with four replicates. The maize cultivars listed in Table 1 were planted using a Nodet Gaugis precision vacuum seeder with $750 \mathrm{~mm}$ row spacing and $130 \mathrm{~mm}$ intra-row spacing resulting in 102,600 seeds/ha. Trial 3 was of a split plot design that also investigated the effects of a narrower row spacing on herbicide performance. For this, half of each $6 \mathrm{~m}$ plot was planted in normal $750 \mathrm{~mm}$ rows while the other half was planted in $375 \mathrm{~mm}$ rows with the intra-row spacing extended to $260 \mathrm{~mm}$ to give the same overall plant population.

The seven treatments in each trial were post-emergence applications of nicosulfuron (Amaze) at $60 \mathrm{~g} / \mathrm{ha}$ plus a tallow amine ethoxylate adjuvant (Amaze Activator) at $0.5 \% \mathrm{v} / \mathrm{v}$, starting at 1 week after maize emergence and applied at weekly intervals for the next 6 weeks. In Trial 2 the first application was delayed 3 days owing to bad weather and subsequent treatments were at weekly intervals after that. New weed growth that appeared in the plots treated at 1-3 weeks after emergence was controlled with a further application of nicosulfuron plus adjuvant at 7 weeks after emergence to keep the plots weed free until harvest. Herbicides were applied with a $\mathrm{CO}_{2}$ powered backpack sprayer applying 300 litres/ha at $200 \mathrm{kPa}$. The nozzles (TeeJet 11004) were arranged to spray down the centre of each row thus minimising direct exposure of the maize plants.

TABLE 1: Details of the three maize trials.

\begin{tabular}{llcccc}
\hline $\begin{array}{l}\text { Trial } \\
\text { number }\end{array}$ & Maize cultivar & $\begin{array}{c}\text { Planting } \\
\text { date }\end{array}$ & $\begin{array}{c}\text { Emergence } \\
\text { date }\end{array}$ & $\begin{array}{c}\text { Date of first } \\
\text { treatment }^{1}\end{array}$ & $\begin{array}{c}\text { Grain } \\
\text { harvest date }\end{array}$ \\
\hline 1 & Pioneer 3527 & 30.10 .98 & 05.11 .98 & 12.11 .98 & 02.05 .99 \\
2 & Pioneer 36H36 & 22.10 .99 & 31.10 .99 & 09.11 .99 & 20.04 .00 \\
3 & Pioneer 3527 & 17.10 .00 & 24.10 .00 & 01.11 .00 & 29.05 .01 \\
\hline
\end{tabular}

${ }^{1}$ Subsequent treatments were applied at weekly intervals from this date.

The following data were collected from each plot prior to application of the postemergence treatment: maize height and leaf area, and weed dry matter and leaf area for both grass and broadleaf weeds. Weed dry matter was determined by cutting and collecting duplicate $0.1 \mathrm{~m}^{2}$ quadrats to ground level in each plot. Leaf area of the maize was determined by video imaging on a moving belt while that for the weeds was by image analysis (ImageTool ver. 2.0, UTHSCSA) of a digitised image of the leaves which had been placed on clear acetate sheets. Visual observations on the efficacy of herbicide treatments and subsequent weed germination were made on several occasions until about 4 weeks after the final application. At the end of the season maize yields were determined by harvesting 50 cobs from the two centre rows of each plot. The cobs were shelled and moisture content determined by oven drying at $80^{\circ} \mathrm{C}$ for $48 \mathrm{~h}$. Grain yields were adjusted to $14 \%$ moisture content and ANOVA used to separate the means. 


\section{RESULTS AND DISCUSSION}

The weeds present in each of the three trials differed markedly. In Trial 1 the principal weeds were willow weed (Polygonum persicaria), fathen (Chenopodium album), summer grass (Digitaria sanguinalis) and smooth witchgrass, with lesser amounts of redroot (Amaranthus powellii) and apple of Peru (Nicandra physalodes). In Trials 2 and 3 there were fewer grass weeds but these were replaced by black nightshade (Solanum nigrum) and spurrey (Spergula arvensis) in Trial 2 and by thorn apple (Datura stramonium) in Trial 3. In Trial 1 the broadleaf and grass weeds contributed equally to the total weed mass for the first 4 weeks, but after this time the dry weight of the broadleaf weeds was about twice that of the grass weeds (Table 2). In Trials 2 and 3 the broadleaf species were $>90 \%$ of the total weed dry matter.

Visual observations showed that nicosulfuron was effective in controlling all these weeds when they were small. In treatments 1-3 the small weeds stopped growing soon after spraying, then shrivelled and rotted within 2 weeks leaving the soil exposed. Under the conditions of these trials nicosulfuron was rapidly dissipated and in these treatments a

TABLE 2: Maize height $(\mathrm{m})$ and leaf area $\left(\mathrm{m}^{2} / \mathrm{ha}\right)$ along with weed dry matter $(\mathrm{kg} / \mathrm{ha})$ and leaf area $\left(\mathrm{m}^{2} / \mathrm{ha}\right)$ for both grass and broadleaf weeds at the time the treatment was applied, and final maize grain yield (tonnes/ha) for Trials 1-3.

\begin{tabular}{|c|c|c|c|c|c|c|c|}
\hline \multirow{2}{*}{$\begin{array}{l}\text { Application } \\
\text { time } \\
(\text { weeks })^{1}\end{array}$} & \multicolumn{2}{|c|}{ Maize } & \multicolumn{2}{|c|}{ Grass } & \multicolumn{2}{|c|}{ Broadleaf } & \multirow{2}{*}{$\begin{array}{l}\text { Maize } \\
\text { grain } \\
\text { yield }\end{array}$} \\
\hline & Height & $\begin{array}{l}\text { Leaf } \\
\text { area }\end{array}$ & $\begin{array}{c}\text { Dry } \\
\text { matter }\end{array}$ & $\begin{array}{l}\text { Leaf } \\
\text { area }\end{array}$ & $\begin{array}{c}\text { Dry } \\
\text { matter }\end{array}$ & $\begin{array}{l}\text { Leaf } \\
\text { area }\end{array}$ & \\
\hline \multicolumn{8}{|l|}{ Trial 1} \\
\hline 1 & 0.14 & 270 & 13 & 321 & 12 & 308 & 11.9 \\
\hline 2 & 0.29 & 925 & 52 & 1350 & 45 & 1094 & 11.7 \\
\hline 3 & 0.44 & 2386 & 254 & 7621 & 136 & 3234 & 12.1 \\
\hline 4 & 0.66 & 5512 & 529 & 23389 & 585 & 14159 & 10.0 \\
\hline 5 & 0.85 & 9466 & 707 & 25254 & 1491 & 22508 & 8.7 \\
\hline 6 & 1.04 & 16326 & 932 & 26076 & 2283 & 27050 & 7.9 \\
\hline 7 & 1.31 & 19631 & 1586 & 42145 & 2381 & 30212 & 8.4 \\
\hline LSD $(\mathrm{P}<0.05)$ & & & & & & 1.53 & \\
\hline \multicolumn{8}{|l|}{ Trial 2} \\
\hline 1 & 0.22 & 790 & 1.1 & 47 & 22 & 204 & 12.9 \\
\hline 2 & 0.37 & 2677 & 2.0 & 84 & 50 & 413 & 11.8 \\
\hline 3 & 0.53 & 5133 & 7.2 & 253 & 111 & 1099 & 12.8 \\
\hline 4 & 0.71 & 8756 & 19.5 & 542 & 320 & 3080 & 12.2 \\
\hline 5 & 0.98 & 13738 & 73.6 & 2512 & 613 & 7562 & 11.4 \\
\hline 6 & 1.37 & 30437 & 175.0 & 3156 & 1481 & 12662 & 9.8 \\
\hline 7 & 1.70 & 44322 & 79.9 & 2968 & 2430 & 22517 & 9.3 \\
\hline LSD $(\mathrm{P}<0.05)$ & & & & & & 1.34 & \\
\hline \multicolumn{8}{|l|}{ Trial 3} \\
\hline 1 & 0.14 & 276 & 0.2 & 5 & 3 & 54 & 10.0 \\
\hline 2 & 0.22 & 669 & 0.6 & 17 & 7 & 108 & 10.8 \\
\hline 3 & 0.32 & 1608 & 2.1 & 18 & 35 & 311 & 9.4 \\
\hline 4 & 0.41 & 3356 & 2.7 & 37 & 93 & 1299 & 9.4 \\
\hline 5 & 0.58 & 5930 & 16.9 & 569 & 276 & 4524 & 10.4 \\
\hline 6 & 0.84 & 12999 & 27.5 & 1087 & 829 & 12067 & 9.1 \\
\hline 7 & 1.16 & 19667 & 76.4 & 2695 & 716 & 19147 & 7.2 \\
\hline LSD $(\mathrm{P}<0.05)$ & & & & & & 1.65 & \\
\hline
\end{tabular}

${ }^{1}$ Time of herbicide application (weeks after emergence of the maize crop). 
second application of nicosulfuron was made at week 7 to control the freshly germinated weeds so that competition from them would not confound the interference effects of the weeds present up to the time of spraying. The weeds present in Treatments 4 and 5 were larger at treatment and they took longer to die back. This, combined with the increasing light exclusion provided by maize plants tended to severely restrict emergence of new weeds. At weeks 6 and 7 (Treatments 6 and 7) the large weeds persisted in the plots for much of the growing season. Most of these weeds were severely checked and stopped growing for several weeks with some eventually dying and others regrowing.

At the time the first treatment was applied, weed cover ranged from ca $0.6-6.2 \%$ (Table 2). Ground cover of weeds rapidly increased and theoretical ground cover (total leaf area/ground area) reached $100 \%$ (i.e. $10,000 \mathrm{~m}^{2} /$ ha total weed leaf area) at about 3 weeks after emergence in Trial 1, at 5 weeks in Trial 2 and 5-6 weeks in Trial 3. Up until this time most weeds were readily controlled by the nicosulfuron, but after this time it appears that the efficacy of the herbicide was compromised by two factors, viz. the large size of the weeds and the inability to achieve good plant coverage due to the smaller weeds being shaded by the larger ones. Several other researchers have reported that for optimum efficacy, nicosulfuron should be applied to weeds less than 150-200 mm tall (e.g. Carey \& Kells 1995; Williams \& Harvey 2000). Guidelines based on weed height unfortunately do not match the growth form of the many weeds that tend to be low growing, such as certain grass weeds or prostrate broadleaf weeds. A better indicator of optimal timing for the application of nicosulfuron would be the weed ground cover. There are two reasons for this. The first is a reduction in herbicide efficacy due to inferior spray distribution on weeds of different sizes, as shown here and in previous publications (James \& Rahman 1993, 1994). The second, as demonstrated by these results, is that from the time theoretical weed groundcover is achieved, maize grain yield is reduced (Table 2). In Trial 1 theoretical ground cover of the weeds occurred about 3 weeks after emergence and maize grain yields were significantly reduced in all the treatments applied after this time. In Trials 2 and 3 on the other hand, theoretical weed cover occurred in weeks 5 and 6 respectively and maize grain yields were significantly reduced only in treatments applied after those dates in each trial.

In Trial 3, there were no significant differences in weed mass, weed cover, maize plant size or grain yields between the two row spacings (data not presented). Thus the expected greater shading from maize plants in the narrow row spacing had little effect on weed growth over the first 7 weeks and the weeds present had the same competitive effect on maize planted at both row spacings.

Results from these trials show that the timing of post-emergence application of nicosulfuron is constrained as much by weed cover as by weed size. When there are high weed populations and total ground cover occurs early, the application window to achieve maximum weed control and crop yield is shortened. Previous trials (James et al. 2000) have demonstrated that use of pre-emergence herbicides reduces overall weed density and thus increases the duration of the application window for effective postemergence treatment with no reduction in grain yield. Combining the results from the present trials with those from previously published work, it would appear that in most years the window lasts for 3-4 weeks after emergence of the maize when weeds are left uncontrolled. However, if a pre-emergence herbicide is used for either grass or broadleaf weed control, then this window can extend up to 6-7 weeks, provided the maize crop is of a height that can still be sprayed without physically damaging the plants.

\section{REFERENCES}

Carey JB, Kells JJ 1995. Timing of total postemergence herbicide applications to maximize weed control and corn (Zea mays) yield. Weed Technology 9: 356-361.

James TK, Rahman A 1993. Adjuvants improve control of warm zone grasses with sulfonylurea herbicides in maize. Proceedings of the 14th Asian-Pacific Weed Science Society Conference: 68-72. 
James TK, Rahman A 1994. Effect of adjuvants and stage of growth on the efficacy of three sulfonylurea herbicides to grass weeds. Proceedings of the 47th New Zealand Plant Protection Conference: 11-16.

James TK, Rahman A 1997. Control of couch (Elytrigia repens) and Mercer grass (Pasplaum distichum) in maize with nicosulfuron. Proceedings of the 50th New Zealand Plant Protection Conference: 467-471.

James TK, Rahman A, Mellsop J 2000. Weed competition in maize crop under different timings for post-emergence weed control. New Zealand Plant Protection 53: 269-272.

Kapusta G, Krausz RF, Khan M, Matthews JL 1994. Effect of nicosulfuron rate, adjuvant, and weed size on annual weed control in corn (Zea mays). Weed Technology 8: 696-702.

Kimura F, Haga T, Sakashita N, Murai S, Fujikawa K 1989. SL-950, a novel sulfonylurea herbicide for corn. Proceedings of the Brighton Crop Protection Conference - Weeds. Pp. 29-34.

Mekki M, Leroux GD 1994. Activity of nicosulfuron, rimsulfuron, and their mixture on field corn (Zea mays), soybean (Glycine max), and seven weed species. Weed Technology 8: 436-440.

Rahman A, James TK 1993. Enhanced activity of nicosulfuron in combination with soilapplied insecticides in corn (Zea mays). Weed Technology 7: 824-829.

Rahman A, James TK, Mellsop JM, Grbavac N 2003. Relationship between soil seedbank and field populations of grass weeds in maize. New Zealand Plant Protection 56: 215-219.

Robinson DK, Monks DW, Schultheis JR, Worsham AD 1993. Sweet corn (Zea mays) cultivar tolerance to application timing of nicosulfuron. Weed Technology 7: 840-843.

Williams BJ, Harvey RG 2000. Effect of nicosulfuron timing on wild-proso millet (Panicum miliaceum) control in sweet corn (Zea mays). Weed Technology 14: 377-382. 